ANALYTICAL ESSAY

\title{
International Peacebuilding and Local Success: Assumptions and Effectiveness
}

\author{
Séverine Autesserre \\ Barnard College, Columbia University
}

\begin{abstract}
Existing research on war and peace lacks analysis of what allows peacebuilding to succeed at the subnational level. Instead, most scholars focus on peacebuilding failure and macro-level dynamics. This is unfortunate because the obstacles to peacebuilding are such that the most puzzling question is why international efforts sometimes succeed, rather than why they fail. The lack of focus on success is also problematic because it results in ambiguous findings. On the one hand, there is an emerging consensus that local conflict resolution is crucial to building peace. There is also an agreement that, all else being equal, international support tends to increase the chances of successful peacebuilding. On the other hand, when international actors have tried to back local initiatives, they have often generated counterproductive consequences and worsened the situation. Should international actors support local peacebuilding processes? If so, how can they actually do this?

Drawing on in-depth interviews, field and participant observations in nine different conflict zones, and document analysis, this article takes the first step in explaining whether, how, why, and under what conditions international interveners (including donors, diplomats, peacekeepers, and the foreign staff of international and non-governmental organizations) can contribute to successful local and bottom-up peace efforts. It makes three central contributions. First, it shows that the policy and scholarly literatures suffer from a dearth of findings on successful international support to local conflict resolution. Second, it emphasizes the critical-and under-researched-role of assumptions in shaping peacebuilding initiatives. Third, it develops a theoretical framework to analyze how assumptions influence international peace efforts. By way of illustration, the article analyzes three widespread assumptions about peacebuilding and the role of peacebuilders. In each case, it challenges assumptions that international interveners take for granted but that are actually unfounded and detrimental, while identifying assumptions that promote peacebuilding effectiveness.
\end{abstract}

Keywords: international peacebuilding, conflict resolution, local peace 


\section{Introduction}

Peacebuilding is a crucial task. More than forty countries around the world are currently in the midst of a war or going through post-conflict reconstruction. This instability heightens the risks of mass atrocities and genocide. It undermines legitimate governments, the rule of law, and universal standards of human dignity. It creates a fertile breeding ground for terrorists and illicit traffickers, providing them with safe havens and funding. It makes states less able to respond to contagious diseases, resulting in widespread pandemics like the recent Ebola crisis. It generates massive refugee flows. Moreover, at times, internal disorder and violence can lead the United States, its allies, China, and Russia to intervene militarily or politically, resulting in potentially destabilizing geopolitical battles, as is currently happening in Syria.

Because the consequences of persistent violence are so severe, international peace interventions have multiplied since the end of the Cold War. United Nations operations (Daniel 2008, 11; Duffey 2000, 142), non-governmental agencies (Barnett 2011, 3-5; Werker and Ahmed 2008, 75), donors (Barnett 2011, 4), diplomatic missions, and regional organizations have become increasingly numerous and influential (Anderson and Olson 2003, 8). For instance, more than 100,000 troops, observers, and police personnel currently serve as United Nations peacekeepers in sixteen operations across four continents (United Nations 2016). This represents the second-largest deployed force abroad after the US military.

Peacebuilding actors accomplish a very wide variety of tasks. The most widespread-and most skeletal-definition of peacebuilding refers to actions aimed at creating, strengthening, and solidifying peace (Boutros-Ghali 1992). At a minimum, it involves reestablishing a measure of security. Tasks therefore include peacemaking - the process of bringing parties in conflict to an agreement through peaceful means-and peacekeeping (United Nations Security Council 2016), which denotes the "deployment of international personnel to help maintain peace and security" after a war (Fortna 2008, 5). Most scholars and policymakers consider several other elements beyond this security dimension. A broad consensus has emerged on the need for socio-economic recovery, which in turn calls for humanitarian and development aid (Collier et al. 2003; United Nations Security Council 2001, para. 18-20). A fierce debate also exists over what types of political institutions and processes are necessary, but most thinkers include statebuilding, justice, and reconciliation, and numerous authors also add democracy (Call 2008, 183-86; United Nations Security Council 2001, para. 10-20). In sum, to use Galtung's (1969) well-known distinction, peacebuilding initiatives aim to create not only "negative peace"- the absence of war and violence-but also "positive peace"-the conditions that make peace sustainable over the long term-both in interstate wars and in civil conflicts.

These peace efforts have achieved many crucial results. They have helped host nation authorities and populations end widespread violence, reestablish security, promote economic development, and organize democratic elections in Cambodia, Liberia, Mozambique, Sierra Leone, and Timor-Leste, among many other places.

Admittedly, although foreign actors routinely contribute to conflict resolution, peacebuilding efficacy relies primarily on the actions, interests, and strategies of domestic entities. Wars can end only when hostile parties at the local, national, and regional levels agree to stop using violence to resolve their differences, and when their fellow citizens concurrently strive to establish and maintain lasting solutions to the conflict. Foreign interveners-including donors, diplomats, peacekeepers, and the foreign staff of international and non-governmental organizations-can, at best, support peace initiatives and undermine efforts to resume violence. 
That being said, external contributions do increase the chances of establishing a durable peace (Doyle and Sambanis 2000; Fortna 2008; Gilligan and Sergenti 2008; Goldstein 2011; Howard 2008; Walter 2002). ${ }^{1}$ Unfortunately, many international peacebuilding efforts never manage actually to promote peace: the rate of failure varies by source from 15 percent (Gilligan and Sergenti 2008) to 75 percent (Weinstein 2005, 11 and 33). ${ }^{2}$

Regrettably, the policy and academic communities lack analytical insights into how to enhance peacebuilding success. Indeed, both research and practice in international peacebuilding have yielded ambiguous findings. On the one hand, there is the above-mentioned agreement that, all else being equal, international support tends to increase the chances of successful peacebuilding. There is also an emerging consensus that local and bottom-up conflict resolution are crucial to controlling violence and promoting reconciliation in many war and postwar environments. ${ }^{3}$ (In this article, "local" means at the level of the individual, the family, the clan, the district, the province, and the ethnic group when it is not a nationallevel one. ${ }^{4}$ ) On the other hand, many instances in which international actors tried to support local initiatives have generated counterproductive consequences. For instance, they have undermined domestic efforts to promote human rights in Malawi (Englund 2006) and resolve grassroots conflicts in the Democratic Republic of Congo-henceforth Congo-and Tajikistan (Gallo and Vanholder 2015; Heathershaw 2009); at times they have even fueled violence, as in Afghanistan (Martin 2014), Congo (Autesserre 2014b), and Uganda (Branch 2011). Combining these conflicting insights raises two central research questions: Should international actors support local peacebuilding processes? If so, how can they actually do this?

To answer these questions, my broad project investigates whether, how, why, and under what conditions international interveners can contribute to successful local and bottom-up peace efforts. To do so, it builds on, refines, and expands my earlier research on international peacebuilding (see notably Autesserre 2010 and $2014 b$ ). This article presents the first findings from this new project. It makes three central contributions, which constitute the first three sections of this paper. First, it demonstrates that the policy and scholarly literatures suffer from a dearth of findings on successful international support to local peace efforts. Second, it emphasizes the crucial-and under-researched-role of assumptions in shaping peacebuilding initiatives. Third, it develops a theoretical framework to analyze how assumptions influence the effectiveness of international peace efforts. By way of illustration, the last part analyzes three widespread assumptions about peacebuilding and the role of peacebuilders. In each case, it challenges assumptions that international interveners take for granted but that are actually unfounded and detrimental, and it identifies assumptions that promote peacebuilding effectiveness. In the conclusion, I highlight the policy and scholarly implications of my analysis, and I emphasize the need for further research to answer fully the two questions at the heart of my broader project.

\footnotetext{
${ }^{1}$ For a dissenting view, see Lund (2003). For a discussion of this debate, see Paris (2011, 351-53) and Autesserre (2014b, 21-23).

${ }^{2}$ For other estimates (all of which use different definitions of "success" and "failure"), see Call (2008, 173-83); Doyle and Sambanis (2006, 74-75); Fortna (2008, 104-16 and 125). For a discussion of these widely divergent estimates, see Autesserre (2014b, 21-23) and Paris (2011, 351-53).

${ }^{3}$ Among many others: Anderson and Wallace (2013); Autesserre (2010); Hughes, Öjendal, and Schierenbeck (2015); Lederach (1997); Leonardsson and Rudd (2015); McGuinness (2012); Mitchell and Hancock (2012); Odendaal (2013); Zelizer and Rubinstein (2009).

"Local peacebuilding projects" thus refers to subnational projects, and "local stakeholders" to the population from the area targeted by a given peacebuilding initiative. These people do not form a homogeneous community: They usually comprise many political, economic, social, and religious subgroups and hold very varied (and at times conflicting) interests and traditions.
} 
This article relies on rich ethnographic material in addition to numerous secondary sources. My ethnographic material includes 718 in-depth interviews, three and a half years of field observations, and participant observations of hundreds of peacebuilding events and projects. I collected this data primarily in Congo (where I traveled regularly between 2001 and 2016). I also draw on research visits to Afghanistan (in 2002), Burundi (where I went several times between 2003 and 2012), Cyprus (in 2011), Israel and the Palestinian Territories (in 2012), Kosovo (in 2000), Nicaragua (in 1998), South Sudan (in 2011), and Timor-Leste (in 2012 and 2016). In addition, I build on participant observations and interviews conducted in the New York headquarters of various international and non-governmental organizations as well as interviews in African, European, North American, and Oceanic capitals (between 1999 and 2016). The article is also informed by a thorough analysis of primary source documents from international programs, an extensive review of available policy and scholarly studies of peacebuilding (during which I paid particular attention to impact studies and randomized control trials), and a systematic review of ninety-seven evaluations of international projects in support of local peace initiatives. ${ }^{5}$

Unlike most existing literature, my analysis does not seek to account for intervention successes or failures at the aggregate (national or international) level. Instead, it considers the relative effectiveness of individual peacebuilding projects and programs and the common factors that contribute to their success. To that end, I use a situation-specific definition of effectiveness that reflects the contested understandings of peace, success, and failure (on these, see Autesserre 2014b, 2124; CDA Collaborative Learning Projects 2011, 3). I consider a peacebuilding project, program, or intervention to be effective when a large majority of implementers (international and local peacebuilders) and intended beneficiaries (including local elite and ordinary citizens) perceive it as having promoted peace in the area of intervention. My definition does not require that a program or project garner universal praise-some individuals or groups will always be dissatisfied. Nor does it demand that the initiative's contributions to the establishment of peace take one specific form over another. Some efforts can directly reduce or prevent violence. Others can do so indirectly by creating the broader conditions that facilitate peace, for instance by strengthening institutions that address conflict. My definition simply reflects a general consensus among the people involved in and affected by a given initiative that it has advanced, in one way or another, the establishment of peace.

\section{Successful International Support to Local Peacebuilding: An Under-Researched Topic}

The scholarly and policy literature on peacebuilding was virtually nonexistent in the early 1990s, but it has grown considerably since then (Pugh 2013, 11). Thanks to this recent research, we now have strong evidence as to the causes of violence and peacebuilding failure. However, we know much less about what allows peacebuilding to succeed. Indeed, just like studies of peace actually often focus on violence (Diehl 2016), studies of peacebuilding-including my previous work (e.g., Autesserre 2010 and 2014b) —overwhelmingly focus on problematic cases, ignoring successful experiences (Autesserre 2014a; Fortna 2008, 2-4; Fortna and Howard 2008; Howard 2008, 2-3). This is unfortunate because, as Fortna (2008) and Howard (2008) note, the obstacles to peacekeeping and peacebuilding are such that the most puzzling question is why international efforts sometimes succeed, rather than why they fail. In addition, this focus leads most analysts to believe that the reasons for peace and peacebuilding success are the inverse of the

\footnotetext{
${ }^{5}$ The review methodology and a list of included evaluations are available upon request.
} 
reasons for war and peacebuilding failures. However, just as this assumption is questionable for peace (Diehl 2016), it is questionable for peacebuilding. For instance, many authors have demonstrated that lack of financial resources is a main cause of peacekeeping failure (e.g., Downs and Stedman 2002; Doyle and Sambanis 2006), but an abundance of resources can be equally problematic (Gallo and Vanholder 2015; Manning and Zürcher 2013, 34; Moore 2013, 5-6).

Of the inquiries that do look at peacebuilding success (usually just a part of larger studies), the majority focus on macro-level dynamics, such as national and international peace processes (e.g., Call and Wyeth 2008; Walter 2002), economic conditions (e.g., Paris 2004), and the specific characteristics of the international interveners, like their mandate (e.g., Doyle and Sambanis 2006; Van der Lijn 2009), vested interests (e.g., Adebajo 2011; Stedman 1997; Zartman 1989), and resources (e.g., Fortna 2008; Hampson 1996). These authors, along with most policymakers, assume that peace achieved on the national and international stages will automatically trickle down to the local spheres. ${ }^{6}$ Consequently, international peacebuilding interventions usually proceed in a top-down fashion, focusing on assuaging national and international sources of conflict (Autesserre 2010, 41-83; Richmond 2005, 149-80).

Yet, local and subnational conflicts often motivate large parts of civil war violence, whether in Afghanistan (Dennys and Zaman 2009), Congo (Autesserre 2010), Timor-Leste (Scambary 2014), or many other past and present conflicts (Justino, Brück, and Verwimp 2013; Kalyvas 2006). Consequently, peacebuilding success at the macro level does not necessarily constitute peace at the subnational level (Lund 2003; Mac Ginty 2006). ${ }^{7}$ As a result, in the past fifteen years, scholars have started studying the local and micro-level dimensions of peacebuilding (see Autesserre 2014a for a review of this literature), and policymakers and practitioners have started paying attention to local conflict resolution.

Among the authors who work on subnational peacebuilding, the consensus is that only a combination of top-down and bottom-up efforts can build a sustainable peace (e.g., Autesserre 2010; Lederach 1997; McGuinness 2012; Zelizer and Rubinstein 2009). Recent research has shown that international interventions, notably the presence of peacekeeping troops, are critical to enabling the success of top-down processes (Beardsley 2012; Doyle and Sambanis 2006; Fortna 2008; Gilligan and Sergenti 2008; Goldstein 2011; Hampson 1996; Howard 2008; Hultman, Kathman, and Shannon 2014; Walter 2002). However, this finding may not apply to peacebuilding at the micro level. In fact, the only bottom-up effort truly successful on a significant scale, Somaliland, is noteworthy precisely for the lack of international involvement (Bradbury 2008, 245-46; Cairns 2006; Eubank 2010; Lewis 2008, ix-x and 95; Menkhaus 1996; Renders 2012, 3).

Worse, research on the local impacts of international efforts has yielded disheartening findings. Costalli (2014) argues that, despite some positive outcomes, peacekeeping deployment does not reduce subsequent violence at the municipal level. Mvukiyehe and Samii (2010) demonstrate that peacekeepers neither promote local security nor help restore local authority. Likewise, both communitydriven reconstruction projects and disarmament, demobilization, and reintegration programs regularly fail to reach many of their intended goals (Gilligan, Mvukiyehe, and Samii 2012; Humphreys, Sanchez de la Sierra, and Van der Windt 2012; Humphreys and Weinstein 2007). Some foreign peace efforts have even increased the number and severity of human rights violations in Uganda (Branch 2011), hampered democracy in Malawi and Tajikistan (Englund 2006; Heathershaw 2009), amplified gender disparities and sexual abuse in Bosnia,

\footnotetext{
${ }^{6}$ For critical discussions of these assumptions, see Autesserre (2010), 41-83; and Manning (2003).

${ }^{7}$ For specific examples on Cambodia, see Peou (2012); on Congo: Autesserre (2010); on Nepal: Denskus (2009), 54; on Tajikistan: Heathershaw (2009).
} 
Congo, Liberia, and Sierra Leone (Simm 2013), disrupted local economies in Congo, Liberia, and South Sudan (Bøås and Jennings in progress), and fueled violence in Congo and Afghanistan (Autesserre 2012; Martin 2014).

There is some research on successful international support to local or bottomup peacebuilding processes. Unfortunately, most of those existing studies focus on one program, initiative, organization, or sector instead of adopting a broader view of the situation (for instance, Ford 2006; Sambunjaka and Simunovićh 2007; Shank and Schirch 2008). This approach overlooks the interplay between various peacebuilding efforts and limits the generalizability of any theoretical findings. Moreover, these studies are often written either as reports by the donor or implementing organization, who try to paint themselves in the best possible light (e.g., McGuinness 2012; Pinnington 2014), or as contracted outside evaluations, which also include biases such as self-censorship, data manipulation, and nonpublication of critical findings (author's interviews, 2010-2016; Church and Rogers 2006, 195). Finally, the handful of scholarly studies on successful international peace efforts at the local level have all produced very different findings (Autesserre 2014b; Cairns 2006; Campbell 2017; Holohan 2005; Moore 2013; Zanotti 2010; Zelizer and Rubinstein 2009). This wide variation in findings is also present in the ninety-seven evaluations of recent international peacebuilding projects that I reviewed for this article. This leaves us with no clear understanding of the mechanisms through which foreign interveners can best contribute to grassroots conflict resolution and which international actors or actions are particularly helpful on the ground.

In sum, existing research lacks analysis of what allows peacebuilding to succeed at the subnational level. As a result, as the next section details, many policymakers and practitioners rely on unsupported assumptions rather than on empirical evidence to formulate and implement their programs.

\section{Understanding the Role of Assumptions in Peacebuilding}

The Critical Role of Assumptions

Studies of what policymakers and practitioners call "theories of change" underscore the crucial role of assumptions in current peacebuilding efforts. Theories of change are not "theories" in the academic understanding of the term; instead, they are "explanations of how and why a set of activities"-for instance, a disarmament project-will achieve desired objectives, such as a more peaceful society (Lederach, Neufeldt, and Culbertson 2007, 25). One might expect all peacebuilding initiatives to be grounded in theories of change that enunciate a clear causal chain and are substantiated by evidence. However, most peace projects instead rely on unsupported assumptions.

Explicit theories of change are absent from many peacebuilding program documents and, "in many cases, theories of change or logical frameworks are not a key part, or a part at all, of the programme-planning process" (Brown et al. 2015, 9, see also 5, 14, and 31). Rather, these programs rest upon implicit-and implicitly shared-theories of change, which are rooted in the project designers' cumulative experience.

The problem with both stated and unstated theories of change is that they are often unrealistic or overly simplistic (Brown et al. 2015; Cameron et al. 2015). Examples abound, such as non-governmental organizations telling their donors that a year-long project will produce democracy (author's interview, 2016) or program documents explaining that "democracy brings stability and elects leaders who can ensure peace" (Cameron et al. 2015, 5). In addition, these theories often include massive leaps in logic (Brown et al. 2015, 9, 11, and 14). A case in point is the expected peacebuilding impact of livelihood programs for victims of sexual 
violence. They rely on a tenuous causal chain, arguing that providing rape victims with sewing machines (or chickens, or the means to set up a beauty salon) will help these women gain financial independence, which will in turn give them greater political voice, and will thus help end sexual violence (as analyzed in Gowrinathan and Cronin-Furman 2015, section 3).

Most peacebuilders also assume that their initiatives will influence war and peace outcomes, but they often do not have evidence to support this belief. Indeed, in its review of all available impact evaluations of peacebuilding initiatives, the Evidence for Peace project found that evaluations often measure "individual outcomes," or "societal and institutional outcomes," but that "there is a dearth of studies that attempt to measure outcomes further along a peacebuilding causal chain-that is, actual peace and violence outcomes," such as displacement and repatriation, intergroup conflict, interpersonal conflict and violence, crime and gang violence, and perceptions of safety and security (Cameron et al. 2015, 55).

All in all, assumptions play a central role in the design of most peacebuilding efforts. It is therefore crucial to examine the assumptions on which policymakers base their support to local programs. Surprisingly, despite their importance, assumptions have been the focus of only one scholarly article on peacebuilding, whose goal is very different from that of my analysis (Jantzi and Jantzi 2009). As a result, we have no theoretical framework to analyze how assumptions influence peacebuilding effectiveness. Building on the extensive literature on related concepts, the rest of this section develops a framework to fill this gap.

\section{The Origin, Diffusion, and Persistence of Assumptions}

While peacebuilders' initiatives can be context specific, their shared assumptions often transcend national and regional boundaries. Indeed, as I have demonstrated in a previous book (Autesserre 2014b), interveners from various geographic, religious, professional, and organizational backgrounds-including civilian, military, and police staff members-form a transnational group. Although there are many differences between the various members of this group, there are also numerous similarities. In particular, most foreign peacebuilders share common practices, habits, and narratives when they are deployed on the ground (Autesserre 2014b). These shared ways of working and thinking are "'free-floating,' transportable, mobile, and transient," and thus can be readily "transplanted in any" conflict and post-conflict context (Verma 2011, 59). Assumptions are a central part of this culture.

Tracing the origin of each assumption I identify is an essential part of my broader project, but it falls beyond the scope of this article. The findings of organizational theorists (DiMaggio and Powell 1983; Weick 1995), sociologists (Berger and Luckmann 1967), and political scientists (Barnett and Finnemore 2004; Finnemore 1996; Krebs 2015; Paris 2003), however, provide two useful starting points. First, assumptions are socially constructed over long periods of time. Second, one can locate their sources on the global stage (for instance, the idea that outsiders have what local populations lack), in the peacebuilding field (the view that good things always go together and that peacebuilding efforts are always necessary), or in practice 8 (the funding of education to promote peace) combined with the belief that lessons from one place can be transferred to another (Autesserre 2014b, 90-93; Stewart and Knaus 2012, 101).

In addition, the literature on frames, habits, and narratives is useful to understand why some assumptions become dominant (Bakke 2014; Hopf 2010; Keck and Sikkink 1998; Lanz 2011). Certain ideas resonate more and are more effective at influencing action because they latch on to preexisting assumptions (for instance, the idea that democracy promotes peacebuilding latching on to the belief

${ }^{8}$ Practice is the very experience of doing peacebuilding on the ground. 
that all good things go together), identify a short and clear causal chain, and suggest a simple solution. As was evident from my fieldwork, these last two features are particularly important in enabling an assumption to achieve and maintain prominence even when it generates negative impacts. Peacebuilders face two conditions that make shortcuts like assumptions or habits indispensable: situations of "cognitive overload"-having to think about more than one task at once-and circumstances with "severe time constraints," in which people lack the time necessary for conscious deliberation (Hopf 2010, 542-43 and 547). International interveners have so many priorities to address in so little time that they do not have much opportunity to question their usual views on peacebuilding and their role as peacebuilders. Moreover, the lack of in-depth knowledge of local situations further incentivizes them to rely on shortcuts, like assumptions, to interpret and respond to their environments (Autesserre 2014b, 68-96).

When donors adopt a given assumption, this also boosts the likelihood that this assumption will achieve preeminence. Indeed, foreign ministries, aid departments, foundations, and United Nations agencies often use their control over financial resources to orient the programs of peacebuilding implementers (nongovernmental organizations, civil-society associations, and local or national authorities). This authority structure creates incentives for on-the-ground peacebuilders to adopt—or, at least, claim to adopt-assumptions in which they may not have originally believed or with which they may actually disagree.

Once assumptions become dominant, a series of formal and informal mechanisms help spread and reproduce them (Autesserre 2014b, 38-39). Graduate programs (in international affairs, aid, or conflict studies) and internal trainings draw from a common set of ideas and encourage a common mindset, which participants then bring to various organizations or theaters of deployment. In addition, international peacebuilders change agencies and countries regularly over the course of their careers, usually carrying over the assumptions acquired from their previous postings to their new positions (Autesserre 2014b, 81-84). In the field, numerous coordination meetings among interveners, as well as frequent informal interactions at parties, bars, and restaurants, provide forums to exchange information, reiterate the prevailing assumptions, and socialize newcomers in the dominant thinking (Autesserre 2014b, 38-39 and 159-69). As with the adoption of habits (Hopf 2010, 542), novices adopt dominant assumptions because of costbenefit calculations, imitation of surrounding peacebuilders, or socialization to the norms of their new environment.

Unfortunately, even when some individuals are initially skeptical, the lack of local knowledge, the focus on short-term and quantifiable results, and the fact that peacebuilders are not accountable to their beneficiaries (Autesserre 2014b, 68-96, 209-13, and 239-45) often prevent interveners from realizing just how detrimental some of their dominant assumptions are and how important it is to dispute them. Confirmation biases and motivated reasoning-the psychological processes that enable people to reach conclusions in line with preexisting beliefs and interests despite overwhelming evidence to the contrary (Janis and Mann 1977; Kunda 1990; Levy and Thompson 2010, 141-50; Lord, Ross, and Lepper 1979) - help further entrench existing assumptions. To make matters worse, as the last section of this article explains, the power dynamics between international and local peacebuilders are such that the latter have little opportunity to challenge even the most counterproductive ideas.

\section{How Assumptions Influence Action}

Research on related concepts, such as frames (Barnett and Finnemore 2004; Eden 2004; Finnemore 1996; Weick 1995), representations (Dunn 2003), 
discourse (Pouliot 2010; Neumann 2008; Wendt 1999, 83-88), habits (Hopf 2010; Swidler 1986), knowledge (Berger and Luckmann 1967), and narratives (Klotz and Lynch 2007; Krebs 2015), is crucial to understanding the process through which assumptions influence peacebuilding efforts and outcomes. Rather than causing or determining action, assumptions orient action by shaping people's understandings of the world. Assumptions make the choice of certain strategies seem natural, appropriate, and effective, while others appear inappropriate, illegitimate, or even unthinkable. For instance, as I explain below, the assumption that more education leads to individuals that are more peaceful makes it seem appropriate and legitimate for peace interveners to devote resources to education programs. In contrast, it seems unthinkable that peacebuilding actors would support corruption because the assumption is that it undermines peace. Assumptions also shape people's views on what counts as a problem: They affect which events will be noticed and which will not, as well as how these events will be interpreted. To continue with the examples of education and corruption, peacebuilders will notice the adverse effects of corruption, but they are less likely to recognize the counterproductive consequences of education programs. Ultimately, assumptions authorize, enable, and justify specific actions while precluding others. These actions in turn reproduce and reinforce existing assumptions. Over time, as various assumptions spread through the peacebuilding field and as they get reproduced and perpetuated, interveners progressively come to take them for granted, seeing them as natural and as the only conceivable modes of thinking and acting.

Of course, this approach and existing explanations that focus on macro-level politics, constraints, mandates, and vested interests (see the first section of this paper) are not mutually exclusive. Instead, they are complementary. The goal of this article is not to challenge all of these existing explanations, but rather to add an important-and thus far unexplored-one to the set of tools scholars and policymakers can use to analyze peacebuilding and its effectiveness.

As the rest of this article shows, many international programs in support of local conflict resolution rely on unsupported, untested, and potentially flawed assumptions about peace, peacebuilding, and the role of outsiders and insiders. These detrimental assumptions often lead peace efforts to be ineffective and even counterproductive. However, when exceptional individuals and organizations challenge these assumptions and adopt other ways of working, peacebuilding is much more effective. My aim in this article is not to provide an exhaustive list of such exceptional organizations and individuals, but rather to analyze a few representative examples for each of the dominant assumptions I examine in order to draw lessons from their experiences.

\section{Challenging Widespread Assumptions}

Good Things Do Not Necessarily Promote Peace, and Bad Things Do Not Necessarily Undermine Peace

A widespread assumption among peacebuilders is that all "good things lead to good things" (Cameron et al. 2015, 5, also 9 and 14). For instance, education is widely seen as "a force for good," and many youth-oriented projects are grounded in the belief that more education leads to more peaceful societies (Bush and Saltarelli 2000, v; Zeus and Chaffin 2011). However, education-including programs funded by international donors as a way to help build peace-can also reinforce violence by promoting intolerance, stereotyping, and ethnic antagonisms (Bush and Saltarelli 2000; King 2014; Spink 2005). Likewise, international actors believe that youth employment programs, skills training, and microfinance help promote peace. Yet, much empirical evidence challenges this claim (Amarasuriya, Gündüz, and Mayer 2009; Blattman and Ralston 2015; Izzi 2013). 
Another widespread belief is that the "surest foundation for peace, both within and between states, is market democracy" (Paris 1997, 56). Accordingly, numerous countries, as well as institutions as diverse as the African Union, the United Nations, the World Bank, and various non-governmental organizations, share a "liberal peace agenda" (Paris 2004; Richmond 2005). This agenda typically emphasizes the organization of free and fair elections, the creation of a market economy, the separation of powers, the reform of the security sector, the rule of law, and the advancement of human rights and civil society. Far from being a "force for good," however, the push toward political liberalization often fuels violence (Autesserre 2010, chapters 3 and 5; Barnett 2006; Newman, Paris, and Richmond 2009; Paris 2004), while the promotion of market liberalization aggravates socioeconomic problems (Richmond and Franks 2009; Paris 2004; Pugh 2005; Tadjbakhsh 2011).

Another unsupported but "widespread, overarching assumption" is that microlevel peace will lead to macro-level peace (Ernstorfer, Chigas, and Vaughan-Lee 2015, 73). Drawing on forty-two case studies, the Reflecting on Peace Practice Program has shown that, for most peacebuilding agencies, "local-level work, by definition, is assumed to be relevant to peace-writ-large" (Ernstorfer et al. 2015, 72). In fact, grassroots initiatives may have a significant impact on a specific village or district, preventing or avoiding violence and tremendously improving the lives of the inhabitants, but carry no influence on macro-level peace (Ernstorfer et al. 2015). . $^{9}$

Conversely, most international interveners believe that undesirable things (like drugs and corruption) run counter to peacebuilding objectives (author's interviews, 2001-2016). As a result, numerous peacebuilding programs focus on fighting undesirable phenomena like drug cultivation, corruption, and illicit businesses. In actuality, such undesirable things do not necessarily undermine peace. In some parts of Afghanistan, drugs and corruption have in fact contributed to political order and statebuilding (Goodhand 2008). Corruption has also contributed to short-term stability in other postwar environments, such as Liberia (Cheng and Zaum 2012; Le Billon 2003). In the Balkans, the arms trade and illicit businesses helped "break a stalemated military situation" and "create the necessary conditions for a negotiated peace" in Bosnia-Herzegovina (Andreas 2009, 38). These industries also strengthened economies throughout the region and supplemented inadequate humanitarian aid (Andreas 2009; Hoare 2015).

In other words, contrary to the dominant assumption among peacebuilders, all good things do not necessarily work together. Education, employment, democracy, and micro-level stability do not necessarily promote peace, while bad things (like drug trafficking, corruption, and arms trade) do not necessarily undermine peacebuilding efforts; in some cases, they can actually promote short-term or long-term peace.

\section{Peacebuilding Efforts Are Not Always Necessary}

International peacebuilding initiatives, by essence, rely on the assumption that they are needed to help build peace. As Koddenbrock's (2016) book explains at length, interveners present their involvement as "normal" and "self-evident." And indeed, of the hundreds of foreign peacebuilders I interviewed, only a handful mentioned that local people may achieve peace on their own. All of the others viewed the necessity of their presence as so obvious that it was not even worth discussing.

\footnotetext{
${ }^{9}$ See Safunu (2012) for an example on Northern Ghana and Autesserre (2014a) for an analysis of the research on this topic.
} 
In fact, outsiders may at times pose obstacles to the process of domestic change. For instance, when talking with foreign interveners, Congolese youth activists emphasize that they would prefer outsiders to leave, because international peacebuilders get in the way of local people trying to hold their government accountable (author's interview, 2016).

Furthermore, peacebuilding efforts as we know them may not always be necessary, as two recent studies show. In their ethnographic analysis of ten cases of war and peace, Richards $(2005,15)$ and his colleagues found that "sometimes peace breaks out even without formal peacemaking efforts." Mac Ginty's (2014) work on "everyday peacebuilding" hints at a similar idea: In their day-to-day lives, ordinary people engage in actions that researchers often view as banal, mundane, and unimportant, and that are unrelated to formal peacebuilding initiatives, but that in fact help prevent local outbreaks of violence and, at times, even directly deal with conflict and tensions.

The assumption that peacebuilding efforts are nevertheless needed persists because of two widespread, central-but incorrect and misleading-assumptions about the role of outsiders and insiders. Indeed, an idea underlying "most international conflict prevention efforts," including early warning, dispute resolution, educational or training programs, and statebuilding, is that interveners "have to bring something new" to conflict zones (Anderson and Wallace 2013, 2). This idea relies on, first, the belief that people living in conflict zones lack something, and second, the related view that international interveners can bring what local people are missing.

\section{Insiders Do Not Necessarily Lack Knowledge and Capacity, and Outsiders Do Not Always Have the Capabilities That Insiders Lack}

Interveners widely believe that inhabitants of conflict zones lack the knowledge, skills, qualities, and resources they need to resolve their own predicaments. ${ }^{10}$ For instance, a French expatriate deployed in eastern Congo explained to me that leaders in the country are unreliable, "so only the ... foreigners are capable of enacting reforms." These negative perceptions reached such a point that, during interviews, other interveners emphasized how "surprised" they were when they met "good" local people, such as hardworking citizens and authorities that were not corrupt or did not try to abuse their positions of power. I heard similar discourse in each of my field sites, from Afghanistan to Israel to Timor-Leste: Interveners viewed local and national authorities as lacking in knowledge, competence, motivation, work ethics, and funding, and local people as similarly deficient in education, capacity, and personal qualities (for specific examples, see Autesserre 2014b, 197-99; Sending 2010, 26-28; Von Billerbeck 2015, 302).

The flipside of this discourse is the assumption that foreign interveners have what local people lack and need. As Tull and Englebert (2008, 134-35) demonstrate in their study of statebuilding in Africa, "the very nature of international reconstruction efforts suggests that the knowledge, capacity, strategies, and resources of external actors are crucial ingredients for success." More precisely, interveners believe that they can bring two primary contributions to conflict zones: resources and knowledge. Surprisingly, even my military contacts focused on these two factors and rarely mentioned security as a potential contribution.

One of the primary modes of engagement between international actors and local organizations is through financial and logistical support (Autesserre 2014b, 205-9; Anderson and Olson 2003, 40; Pouligny 2004, 245-51). My local

\footnotetext{
${ }^{10}$ It is outside the scope of this paper to examine local reactions to the international views documented in this section as well as the obstacles these reactions generate for peacebuilding efforts. Readers interested in these topics can find in-depth analysis and extensive ethnographic data in Autesserre (2014b).
} 
interviewees often emphasized that the interveners' resources are among their most significant contributions, as they provide certain local peacebuilders with the funds and logistical assets necessary to implement their programs.

However, international funding mechanisms can actually destroy local capacities and projects rather than enable them (author's interviews; Gallo and Vanholder 2015; Pinnington 2014). All in all, while international resources are often crucial to support local conflict resolution efforts (Anderson, Brown, and Jean 2012; Autesserre 2014b, 205-9), badly informed assistance can do more harm than good (Branch 2011; Englund 2006; Gallo and Vanholder 2015; Heathershaw 2009; Martin 2014).

Whether international interveners channel resources effectively or poorly-and thus support local efforts instead of undermining them-largely depends on how interveners value local knowledge and input (Autesserre 2014b). Indeed, due to various social and historical dynamics, a knowledge hierarchy has developed in peacebuilding (Autesserre 2014b, 68-79; Anderson et al. 2012, 27-28 and 31; Apthorpe 2011, 200 and 202; Englebert and Tull 2008, 134-35). Today, the most valued expertise is that of foreign interveners who are trained in peacebuilding techniques and who have extensive experience in a variety of conflict zones. By contrast, and although there are exceptions, country knowledge is much less valued, and the knowledge of local people is usually trivialized. This knowledge hierarchy legitimates and justifies the interveners' claim that they have the capacity and expertise necessary to help resolve the host populations' problems.

The story of Michel Losembe illustrates how this assumption drives peacebuilding actions. This Congolese businessman told me that he thought foreign peacebuilders were talking down to local counterparts, and that they did not take the ideas of local people into account. Losembe is from a mixed background-he has Belgian, Portuguese, and Congolese ancestors. During a meeting abroad, he conducted an experiment. Instead of introducing himself as a Congolese, as he usually did, he pretended to be from Puerto Rico. The result was clear: The individuals with whom he met perceived him as much more credible, and he had much more influence, when he passed as an outsider.

The problem is that outsiders do not necessarily have the knowledge required to build peace in host countries (Autesserre 2014b, part 1; Pugh 2013). In fact, they often do not even speak the local languages, limiting their ability to interact with the local population. Out of the 140 diplomats working at the UK embassy in Kabul in 2010, only three "spoke an Afghan language" (Mac Ginty 2011, 112). Out of the 1,700 United Nations police deployed in Haiti in 2005, only one hundred spoke French or Creole (Meharg 2009, 136). Conditions were similar in Cyprus and Sudan, where I met only a handful of non-governmental, diplomatic, military, or United Nations personnel who had a command of Greek or Turkish, or Arabic or Nuer.

Conversely, as Anderson and Wallace emphasize, "systems and skills to prevent overt violence between groups already exist in every society" (2013, 2). And indeed, in each of my field sites, I met expatriates who pointed to local and national authorities who had the knowledge, competence, motivation, work ethics, and skills essential to peacebuilding, and to local people who were intelligent, knowledgeable, selfless, reliable, honest, and hardworking.

These exceptional interveners challenged the assumptions developed in this section, and they emphasized that, to be effective, peace efforts must draw on the knowledge of both insiders and outsiders. ${ }^{11}$ Local and foreign peacebuilders with various competencies each contribute different "perspectives, networks, assets,

\footnotetext{
${ }^{11}$ For a similar claim, see Anderson and Olson (2003, chapter 5); Anderson et al. (2012); Autesserre (2014b, 64-67 and 71-73); Campbell $(2010,11,14,16,25,52-59$, and 69); CDA Collaborative Learning Projects (2010, 25); Mac Ginty (2008, 141-43); McGuinness (2012); Ó Súilleabháin (2015).
} 
and leverage with particular constituencies," all of which are essential to peacebuilding (Anderson and Olson 2003, 35). As Anderson and Olson (2003, 42) have demonstrated, these various types of peacebuilders make the greatest contributions to peace when they work together, each challenging the biases of the other. The communities that "opted out of war" in Colombia, the Philippines, and Sri Lanka are prime examples of this kind of successful cooperation (Anderson and Wallace 2013, 85-86 and 129-42). While the idea of "peace communities" or "peace zones" came from outsiders, foreign interveners let local people decide on the specific approaches to implementation. One of the most decisive strategies the insiders adopted was to work with foreign interveners in order to use "the power of international public opinion" to pressure surrounding armed groups into not attacking their communities.

\section{Conclusion}

Violence disrupts the lives of close to one and a half billion people (International Dialogue on Peacebuilding and Statebuilding 2016); it damages the fabric of their societies and shapes the political institutions that govern them. Most of these people yearn for the day peace will eventually prevail. International interventions can help achieve this goal, but they often fail to make their intended impact, and they sometimes worsen the situation. It is therefore crucial to increase the effectiveness of international peace efforts.

Since I started working on war and peace issues seventeen years ago, I have heard a constant refrain: Policymakers and practitioners deplore that many of their standard peacebuilding templates and techniques are ineffective, but that they nevertheless have to continue using these models because no one has yet offered a convincing alternative. Recipients of intervention lament that, although international support could help decrease ongoing tensions, it rarely reaches its full potential. As a result, peacebuilders often request research on initiatives that have succeeded in promoting peace in other parts of the world and that could serve as models for their own efforts.

Further investigation of successful local peacebuilding initiatives, the contributions of foreign actors to such processes, and the elements that shape effective international action at the grassroots level is necessary to build the credible alternatives that are so sorely needed. This article-the first of a broader projectnevertheless provides a jumping-off point. In order to help change the basic premises on which many programs rely, I have emphasized the role of assumptions in influencing the effectiveness of international peacebuilding.

Many international programs in support of local conflict resolution rely on unsupported and flawed assumptions, such as: Good things always go together; peacebuilding efforts are always necessary; and insiders lack the capacity and knowledge to resolve their own predicaments. As a result, these international peace efforts end up being ineffective and even counterproductive. By contrast, programs that rely on different assumptions-such as: Undesirable practices may help promote peace, peacebuilding efforts are not always necessary, and insiders have much of the required knowledge and capacity-are much more effective at supporting local actors to build long-term, sustainable peace.

\section{Acknowledgements}

I am grateful to Maia Bix, Rekha Kennedy, Erik Lin-Greenberg, and Meena Roldan Oberdick for their excellent research assistance, and to Charles Call, William Durch, Pamina Firchow, Janosch Kullenberg, Jessica Steinberg, Kerstin Tomiak, and seminar participants at the City University of New York, Colgate University, the University of Virginia, and the University of Washington for their very helpful 
feedback on various drafts. I also thank my donors for generously funding this project. This article was made possible by grants from the Carnegie Corporation of New York, the Folke Bernadotte Academy, and the Gerda Henkel Foundation. The statements made and views expressed are solely my responsibility.

\section{References}

Adebajo, Adekeye. 2011. UN Peacekeeping in Africa: From the Suez Crisis to the Sudan Conflicts. Boulder, CO: Lynne Rienner Publishers.

Amarasuriya, Harini, Canan Gündüz, and Markus Mayer. 2009. Rethinking the Nexus Between Youth, Unemployment and Conflict: Perspectives from Sri Lanka. London: International Alert.

Anderson, Mary, Dayna Brown, and Isabella Jean. 2012. Time to Listen: Hearing People on the Receiving End of International Aid. Cambridge: CDA Collaborative Learning Project.

Anderson, Mary, and Lara Olson. 2003. Confronting War: Critical Lessons for Peace Practitioners. Cambridge: Collaborative for Development Action.

Anderson, Mary, and Marshall Wallace. 2013. Opting Out of War: Strategies to Prevent Violent Conflict. Boulder, CO: Lynne Rienner Publishers.

Andreas, Peter. 2009. "Symbiosis Between Peace Operations and Illicit Business in Bosnia." International Peacekeeping 16 (1): 33-46.

Apthorpe, Raymond. 2011. "Who Is International Aid? Some Personal Observations." In Inside the Everyday Lives of Development Workers: The Challenges and Futures of Aidland, edited by Anne-Meike Fechter and Heather Hindman, 193-210. Sterling, VA: Kumarian Press.

Autesserre, SÉverine. 2010. The Trouble with the Congo: Local Violence and the Failure of International Peacebuilding. New York: Cambridge University Press.

—. 2012. "Dangerous Tales: Dominant Narratives on the Congo and Their Unintended Consequences." African Affairs 111 (443): 202-22.

—. 2014a. "Going Micro: Emerging and Future Peacebuilding Research." International Peacekeeping 21 (4): 492-500.

- 2014b. Peaceland: Conflict Resolution and the Everyday Politics of International Intervention. New York: Cambridge University Press.

Bakke, Kristin. 2014. "Help Wanted? The Mixed Record of Foreign Fighters in Domestic Insurgencies." International Security 38 (4): 150-87.

Barnett, Michael. 2006. "Building a Republican Peace: Stabilizing States after War." International Security 30 (4): 87-112.

—. 2011. Empire of Humanity: A History of Humanitarianism. Ithaca, NY: Cornell University Press.

Barnett, Michael, and Martha Finnemore. 2004. Rules for the World: International Organizations in Global Politics. Ithaca, NY: Cornell University Press.

Beardsley, Kyle. 2012. "UN Intervention and the Duration of International Crises." Journal of Peace Research 49 (2): 335-49.

Berger, Peter, and Thomas Luckmann. 1967. The Social Construction of Reality: A Treatise in the Sociology of Knowledge. Garden City, NY: Doubleday.

Blattman, Christopher, and Laura Ralston. 2015. "Generating Employment in Poor and Fragile States: Evidence from Labor Market and Entrepreneurship Programs." Working Paper, Harris School of Public Policy, University of Chicago and World Bank. Accessed January 2017. http:// dx.doi.org/10.2139/ssrn.2622220.

Bøås, Morten, and Kathleen Jennings. In progress. Peacekeeping and the City: The Peacekeeping Economy in Liberia, DR Congo and South Sudan. Oslo, Norway: FAFO and NUPI.

Boutros-Ghali, Boutros. 1992. An Agenda for Peace: Preventive Diplomacy, Peacemaking and Peace-Keeping. New York: United Nations.

Bradbury, Mark. 2008. Becoming Somaliland. Bloomington: Indiana University Press.

Branch, Adam. 2011. Displacing Human Rights: War and Intervention in Northern Uganda. New York: Oxford University Press.

Brown, Annette, Faith McCollister, Drew Cameron, and Jennifer Ludwig. 2015. The Current State of Peacebuilding Programming and Evidence. 3ie Scoping Paper 2. New Delhi: International Initiative for Impact Evaluation (3ie).

Bush, Kenneth, and Diana Saltarelli. 2000. The Two Faces of Education in Ethnic Conflict: Towards a Peacebuilding Education for Children. Florence, Italy: UNICEF.

Cairns, Rosemary Margaret. 2006. "Islands of Success in Failed States: Models for International Peacebuilding?” UMI diss., Royal Roads University. ProQuest (MR14390). 
Call, Charles. 2008. "Knowing Peace When You See It: Setting Standards for Peacebuilding Success." Civil Wars 10 (2): 173-94.

Call, Charles, and Vanessa Wyeth. 2008. Building States to Build Peace. Boulder, CO: Lynne Rienner Publishers.

Cameron, Drew, Annette Brown, Anjini Mishra, Mario Picon, Hisham Esper, Flor Calvo, and Katia Peterson. 2015. Evidence for Peacebuilding Evidence Gap Map. New Delhi: International Initiative for Impact Evaluation (3ie).

Campbell, Susanna. 2010. Independent External Evaluation: Peacebuilding Fund Projects in Burundi. New York: United Nations Peacebuilding Fund.

- 2017. Global Governance and Local Peace: Accountability and Performance in International Peacebuilding. New York: Cambridge University Press.

CDA Collaborative Learning Projects. 2010. The Listening Project Issue Paper: The Role of Staffing Decisions. Cambridge: CDA Collaborative Learning Projects.

CDA Collaborative Learning Projects. 2011. Local Perceptions of International Engagement in Fragile States and Situations. Cambridge: CDA Collaborative Learning Projects.

Cheng, Christine, and Dominik Zaum. 2012. Corruption and Post-Conflict Peacebuilding: Selling the Peace. Abingdon, UK: Routledge.

Church, Cheyanne, and Marks Rogers. 2006. Designing for Results: Integrating Monitoring and Evaluation in Conflict Transformation Programs. Washington, DC: Search for Common Ground.

Collier, Paul, V. L. Elliott, Havard Hegre, Anke Hoeffler, Marta Reynal-Querol, and Nicholas Sambanis. 2003. Breaking the Conflict Trap: Civil War and Development Policy. New York: Oxford University Press.

Costalli, Stefano. 2014. "Does Peacekeeping Work? A Disaggregated Analysis of Deployment and Violence Reduction in the Bosnian War." British Journal of Political Science 44 (2): 357-80.

Daniel, Donald. 2008. "Why So Few Troops from Among So Many?" In Peace Operations: Trends, Progress, and Prospects, edited by Donald Daniel, Patricia Taft, and Sharon Wiharta, 47-62. Washington, DC: Georgetown University Press.

Dennys, Christian, and Idrees Zaman. 2009. Trends in Local Afghan Conflicts: Synthesis Paper. Kabul, Afghanistan: Cooperation for Peace and Unity.

Denskus, Tobias. 2009. "The Fragility of Peacebuilding in Nepal." Peace Review 21 (1): 54-60.

Dienl, Paul. 2016. "Exploring Peace: Looking Beyond War and Negative Peace." International Studies Quarterly 60 (1): 1-10

DiMaggio, Paul, and Walter Powell. 1983. "The Iron Cage Revisited: Institutional Isomorphism and Collective Rationality in Organizational Fields.” American Sociological Review 48 (2): 147-60.

Downs, George, and Stephen John Stedman. 2002. "Evaluation Issues in Peace Implementation." In Ending Civil Wars: The Implementation of Peace Agreements, edited by Stephen John Stedman, Donald Rothchild, and Elizabeth M. Cousens, 43-69. London: Lynne Rienner.

Doyle, Michael, and Nicholas Sambanis. 2000. "International Peacebuilding: A Theoretical and Quantitative Analysis.” American Political Science Review 94 (4): 779-801.

- 2006. Making War and Building Peace: United Nations Peace Operations. Princeton, NJ: Princeton University Press.

Duffey, TAmara. 2000. "Cultural Issues in Contemporary Peacekeeping." International Peacekeeping 7 (1): 142-68.

Dunn, Kevin. 2003. Imagining the Congo: The International Relations of Identity. New York: Palgrave Macmillan.

Eden, Lynn. 2004. Whole World on Fire: Organizations, Knowledge, and Nuclear Weapons Devastation. Ithaca, NY: Cornell University Press.

Englebert, Pierre, and Denis Tull. 2008. "Postconflict Resolution in Africa: Flawed Ideas About Failed States." International Security 32 (4): 106-39.

Englund, Harri. 2006. Prisoners of Freedom: Human Rights and the African Poor. Berkeley: University of California Press.

Ernstorfer, Anita, Diana Chigas, and Hannah Vaughan-Lee. 2015. "From Little to Large: When Does Peacebuilding Add Up?” Journal of Peacebuilding Ev Development 10 (1): 72-77.

Eubank, Nicholas. 2010. Peace-Building without External Assistance: Lessons from Somaliland. Washington, DC: Center for Global Development.

Finnemore, Martha. 1996. "Norms, Culture, and World Politics: Insights from Sociology's Institutionalism." International Organization 50 (2): 325-47.

Ford, Chad. 2006. "Peace and Hoops: Basketball as a Role Player in Sustainable Peacebuilding." Willamette Law Review 42 (4): 709-35. 
Fortna, Virginia Page. 2008. Does Peacekeeping Work? Shaping Belligerents' Choices after Civil War. Princeton, NJ: Princeton University Press.

Fortna, Virginia Page, and Lise Morjé Howard. 2008. "Pitfalls and Prospects in the Peacekeeping Literature.” Annual Review of Political Science 11 (1): 283-301.

Gallo, Carol Jean, and Pieter Vanholder. 2015. "From the Ivory Tower to the Boots on the Ground: Conflict Transformation Theory and Peacebuilding in the Democratic Republic of Congo." Paper presented at the International Studies Association Annual Convention, New Orleans, Louisiana.

Galtung, Johan. 1969. "Violence, Peace, and Peace Research.” Journal of Peace Research 6 (3): 167-91.

Gilligan, Michael, Eric Mvukiyehe, and Cyrus Samit. 2012. "Reintegrating Rebels into Civilian Life: Quasi-Experimental Evidence from Burundi.” Journal of Conflict Resolution 57 (4): 598-626.

Gilligan, Michael, and Ernest Sergenti. 2008. "Do UN Interventions Cause Peace? Using Matching to Improve Causal Inference.” Quarterly Journal of Political Science 3 (2): 89-122.

Goldstein, Joshua. 2011. Winning the War on War. New York: Penguin.

Goodhand, Jonathan. 2008. "Corrupting or Consolidating the Peace? The Drugs Economy and PostConflict Peacebuilding in Afghanistan.” International Peacekeeping 15 (3): 405-23.

Gowrinathan, Nimmi, and Kate Cronin-Furman. 2015. The Forever Victims? Tamil Women in Post-War Sri Lanka. New York: Colin Powell School for Civic and Global Leadership, City College of New York.

Hampson, Fen Osler. 1996. Nurturing Peace: Why Peace Settlements Succeed or Fail. Washington, DC: US Institute of Peace Press.

Heathershaw, John. 2009. Post-Conflict Tajikistan: The Politics of Peacebuilding and the Emergence of Legitimate Order. London: Routledge.

Hoare, Jemma. 2015. "The Balkan Arms Trade: A Growing Threat, or Growing Peace?" Insight on Conflict, April 15. Accessed January 2017. http://www.insightonconflict.org/2015/04/balkan-armstrade-threat-or-peace/.

Holohan, Anne. 2005. Networks of Democracy: Lessons from Kosovo for Afghanistan, Iraq, and Beyond. Stanford, CA: Stanford University Press.

Hopf, Ted. 2010. "The Logic of Habit in International Relations." European Journal of International Relations 16 (4): 539-61.

Howard, Lise Morjé. 2008. UN Peacekeeping in Civil Wars. New York: Cambridge University Press.

Hughes, Caroline, Joakim Öjendal, and Isabell Schierenbeck. 2015. "The Struggle Versus the SongThe Local Turn in Peacebuilding: An Introduction.” Third World Quarterly 36 (5): 817-24.

Hultman, Lisa, Jacob Kathman, and Megan Shannon. 2014. "Beyond Keeping Peace: United Nations Effectiveness in the Midst of Fighting." American Political Science Review 108 (4): 737-53.

Humphreys, Macartan, Raul Sanchez de la Sierra, and Peter Van der Windt. 2012. Social and Economic Impacts of Tuungane: Final Report on the Effects of a Community Driven Reconstruction Program in Eastern Democratic Republic of Congo. New York: Columbia University. Accessed January 2017. http:/ / cu-csds.org/wp-content/uploads/2012/06/20120622-FINAL-REPORT.pdf.

Humphreys, Macartan, and Jeremy M. Weinstein. 2007. "Demobilization and Reintegration." Journal of Conflict Resolution 51 (4): 531-67.

International Dialogue on Peacebuilding and Statebuilding. 2016. "The New Deal." Accessed January 2017. http://www.pbsbdialogue.org/en/new-deal/about-new-deal/.

IzZi, Valeria. 2013. "Just Keeping Them Busy? Youth Employment Projects as a Peacebuilding Tool." International Development Planning Review 35 (2): 103-17.

Janis, Irving, and Leon Mann. 1977. Decision Making: A Psychological Analysis of Conflict, Choice, and Commitment. New York: Free Press.

Jantzi, Terrence, and Vernon Jantzi. 2009. "Development Paradigms and Peacebuilding Theories of Change: Analysing Embedded Assumptions in Development and Peacebuilding." Journal of Peacebuilding E Development 5 (1): 65-80.

Justino, Patricia, Tilman Brück, and Philip Verwimp, eds. 2013. A Micro-Level Perspective on the Dynamics of Conflict, Violence, and Development. Oxford: Oxford University Press.

Kalyvas, Stathis. 2006. The Logic of Violence in Civil War. New York: Cambridge University Press.

Keck, Margaret, and Kathryn Sikkink. 1998. Activists Beyond Borders: Advocacy Networks in International Politics. Ithaca, NY: Cornell University Press.

King, Elisabeth. 2014. From Classrooms to Conflict in Rwanda. New York: Cambridge University Press.

Klotz, Audie, and Cecelia Lynch. 2007. Strategies for Research in Constructivist International Relations. Armonk, NY: M. E. Sharpe.

Koddenbrock, Kai. 2016. The Practice of Humanitarian Intervention: Aid Workers, Agencies and Institutions in the Democratic Republic of the Congo. London: Routledge.

Krebs, Ronald. 2015. Narrative and the Making of US National Security. New York: Cambridge University Press. 
Kunda, Ziva. 1990. "The Case for Motivated Reasoning.” Psychological Bulletin 108 (3): 480-98.

LAnz, DAvid. 2011. "The Globalisation of Darfur: Making Sense of a Trajectory from Forgotten Conflict to Global Cause Célèbre." Paper presented at the International Studies Association Annual Convention, Montreal, Quebec.

Le Billon, Philippe. 2003. "Buying Peace or Fuelling War: The Role of Corruption in Armed Conflicts.” Journal of International Development 15 (4): 413-26.

Lederach, John Paul. 1997. Building Peace: Sustainable Reconciliation in Divided Societies. Washington, DC: US Institute of Peace Press.

Lederach, Jean Paul, Reina Neufeldt, and Hal Culbertson. 2007. Reflective Peacebuilding: A Planning, Monitoring, and Learning Toolkit. Notre Dame: Joan B. Kroc Institute for International Peace Studies, University of Notre Dame.

Leonardsson, Hanna, and Gustav Rudd. 2015. "The 'Local Turn' in Peacebuilding: A Literature Review of Effective and Emancipatory Local Peacebuilding.” Third World Quarterly 36 (5): 825-39.

Levy, Jack, and William Thompson. 2010. Causes of War. Malden, MA: Wiley-Blackwell.

Lewis, Joan. 2008. Understanding Somalia and Somaliland: Culture, History, Society. New York: Columbia University Press.

Lord, Charles, Lee Ross, and Mark Lepper. 1979. "Biased Assimilation and Attitude Polarization: The Effects of Prior Theories on Subsequently Considered Evidence." Journal of Personality and Social Psychology 37 (11): 2098-109.

Lund, Michael. 2003. What Kind of Peace Is Being Built? Taking Stock of Post-Conflict Peacebuilding and Charting Future Directions. Ottawa: International Development Research Centre.

Mac Ginty, Roger. 2006. No War, No Peace: The Rejuvenation of Stalled Peace Processes and Peace Accords. London: Palgrave Macmillan.

—. 2008. "Indigenous Peace-Making Versus the Liberal Peace." Cooperation and Conflict 43 (2): $139-63$.

—. 2011. International Peacebuilding and Local Resistance: Hybrid Forms of Peace. London: Palgrave Macmillan.

—. 2014. "Everyday Peace: Bottom-Up and Local Agency in Conflict-Affected Societies." Security Dialogue 45 (6): 548-64.

Manning, Carrie. 2003. "Local Level Challenges to Post-Conflict Peacebuilding." International Peacekeeping 10 (3): 25-43.

Manning, Carrie, and Christoph Zürcher. 2013. Costly Democracy: Peacebuilding and Democratization after War. Palo Alto, CA: Stanford University Press.

Martin, Mike. 2014. An Intimate War: An Oral History of the Helmand Conflict, 1978-2012. London: Hurst.

McGuinness, Kate. 2012. Local First: Development for the Twenty-First Century. London: Peace Direct.

Meharg, Sarah Jane. 2009. Measuring What Matters in Peace Operations and Crisis Management. Montreal: McGill-Queen's University Press.

Menkhaus, Ken. 1996. "International Peacebuilding and the Dynamics of Local and National Reconciliation in Somalia.” International Peacekeeping 3 (1): 42-67.

Mitchell, Christopher, and Landon Hancock, eds. 2012. Local Peacebuilding and National Peace: Interaction Between Grassroots and Elite Processes. London: Bloomsbury Academic.

Moore, Adam. 2013. Peacebuilding in Practice: Local Experience in Two Bosnian Towns. Ithaca, NY: Cornell University Press.

Mvukitehe, Eric, And Cyrus SamiI. 2010. "The Subtle Effects of Peacekeeping: Evidence from Liberia." Paper presented at the American Political Science Association Annual Meeting, Washington, DC.

Neumann, Iver. 2008. "Discourse Analysis." In Qualitative Methods in International Relations: A Pluralist Guide, edited by Audie Klotz and Deepa Prakash, 61-77. New York: Palgrave.

Newman, Edward, Roland Paris, and Oliver Richmond, eds. 2009. New Perspectives on Liberal Peacebuilding. New York: United Nations University Press.

Ó Súllleabhárn, Andrea. 2015. Leveraging Local Knowledge for Peacebuilding and Statebuilding in Africa. New York: International Peace Institute.

Odendaal, Andries. 2013. A Crucial Link: Local Peace Committees and National Peacebuilding. Washington, DC: US Institute of Peace.

Paris, Roland. 1997. "The Perils of Liberal International Peacebuilding." International Security 22 (2): 54-89.

- 2003. "Peacekeeping and the Constraints of Global Culture." European Journal of International Relations 9 (3): 441-73.

- 2004. At War's End: Building Peace after Civil Conflict. New York: Cambridge University Press. 
2011. "Critiques of Liberal Peace." In A Liberal Peace? The Problems and Practices of Peacebuilding, edited by Susanna Campbell, David Chandler, and Meera Sabaratnam, 31-54. London: Zed Books.

Peou, Sorpong. 2012. "Violence in Post-War Cambodia." In The Peace in Between: Post-War Violence and Peacebuilding, edited by Astri Suhrke and Mats Berdal, 192-210. New York: Routledge.

Pinnington, Rosie. 2014. Local First in Practice: Unlocking the Power to Get Things Done. London: Peace Direct.

Pouligny, BÉAtrice. 2004. Ils Nous Avaient Promis la Paix: Opérations de l'ONU et Populations Locales. Paris: Presses de la Fondation Nationale des Sciences Politiques.

Pouliot, Vincent. 2010. International Security in Practice: The Politics of NATO-Russia Diplomacy. New York: Cambridge University Press.

Pugh, Michael. 2005. "The Political Economy of Peacebuilding: A Critical Theory Perspective." International Journal of Peace Studies 10 (2): 23-42.

—. 2013. "The Problem-Solving and Critical Paradigms." In Routledge Handbook of Peacebuilding, edited by Roger Mac Ginty, 11-24. New York: Routledge.

Renders, Marleen. 2012. Consider Somaliland: State-Building with Traditional Leaders and Institutions. Boston, MA: Brill.

Richards, Paul, ed. 2005. No Peace, No War: An Anthropology of Contemporary Armed Conflicts. Oxford: James Currey.

Richmond, Oliver. 2005. The Transformation of Peace. New York: Palgrave Macmillan.

Richmond, Oliver, and Jason Franks. 2009. Liberal Peace Transitions: Between Statebuilding and Peacebuilding. Edinburgh, UK: Edinburgh University Press.

Safunu, Banchani John-Paul. 2012. Do Grassroots Approaches and Mobilization for Development Contribute to Post-Conflict Peacebuilding? The Experience of Northern Ghana. Nairobi: Africa Leadership Center.

Sambunjaka, Dario, and Vladimir Šmunović. 2007. "Peace through Medical Education in Bosnia and Herzegovina." The Lancet 369 (9565): 905.

Scambary, James. 2014. "When the Personal Becomes Political: Informal Security Groups and the Dynamics of Communal Conflict in East Timor." PhD diss., Canberra: Australian National University.

Sending, Ole Jacob, ed. 2010. Learning to Build a Sustainable Peace: Ownership and Everyday Peacebuilding. Bergen: Chr. Michelsen Institute.

Shank, Michael, and Lisa Schirch. 2008. "Strategic Arts-Based Peacebuilding." Peace and Change 33 (2): 217-42.

Simm, Gabrielle. 2013. Sex in Peace Operations. London: Cambridge University Press.

Spink, Jeaniene. 2005. "Education and Politics in Afghanistan: The Importance of an Education System in Peacebuilding and Reconstruction." Journal of Peace Education 2 (2): 195-207.

Stedman, Stephen John. 1997. "Spoiler Problems in Peace Processes." International Security 22 (2): $5-53$.

Stewart, Rory, and Gerald Knaus. 2012. Can Intervention Work? New York: W. W. Norton \& Co.

Swidler, Ann. 1986. "Culture in Action: Symbols and Strategies." American Sociological Review 51 (2): 273-86.

Tadjbakhsh, Shahrbanou. 2011. Rethinking the Liberal Peace: External Models and Local Alternatives. London: Routledge.

United Nations. 2016. "Peacekeeping Fact Sheet as of 31 December 2016." United Nations Department of Peacekeeping Operations. Last modified December 31. Accessed January 2017 http://www.un.org/en/peacekeeping/resources/statistics/factsheet.shtml.

United Nations Security Council. 2001. No Exit without Strategy: Security Council Decision-Making and the Closure or Transition of United Nations Peacekeeping Operations. New York: United Nations.

United Nations Security Council. 2016. Resolution 2282. New York: United Nations.

van der Lijn, JAÏr. 2009. "If Only There Were a Blueprint! Factors for Success and Failure of UN Peace-Building Operations.” Journal of International Peacekeeping 12 (1-2): 45-71.

Verma, Ritu. 2011. "Intercultural Encounters, Colonial Continuities and Contemporary Disconnects in Rural Aid." In Inside the Everyday Lives of Development Workers: The Challenges and Futures of Aidland, edited by Anne-Meike Fechter and Heather Hindman, 59-82. Sterling, VA: Kumarian Press.

Von Billerbeck, Sarah. 2015. "Local Ownership and UN Peacebuilding: Discourse Versus Operationalization.” Global Governance 21 (2): 299-315.

Walter, Barbara. 2002. Committing to Peace: The Successful Settlement of Civil Wars. Princeton, NJ: Princeton University Press.

WeICK, KarL. 1995. Sensemaking in Organizations. Thousand Oaks, CA: Sage Publications. 
Weinstein, Jeremy. 2005. Autonomous Recovery and International Intervention in Comparative Perspective. Washington, DC: Center for Global Development.

Wendt, Alexander. 1999. Social Theory of International Politics. Cambridge: Cambridge University Press.

Werker, Eric, and Faisal Ahmed. 2008. "What Do Nongovernmental Organizations Do?" Journal of Economic Perspectives 22 (2): 73-92.

Zanotti, Laura. 2010. "Cacophonies of Aid, Failed State Building and NGOs in Haiti: Setting the Stage for Disaster, Envisioning the Future.” Third World Quarterly 31 (5): 755-71.

Zartman, William. 1989. Ripe for Resolution: Conflict and Intervention in Africa. New York: Oxford University Press.

Zelizer, Craig, and Robert Rubinstein. 2009. Building Peace: Practical Reflections from the Field. Sterling, VA: Kumarian Press.

Zeus, Barbara, and Josh Chaffin. 2011. Education for Crisis-Affected Youth: A Literature Review. New York: Inter-Agency Network for Education in Emergencies. 